\title{
Hermeneutics and Science Education: the Role of History of Science
}

\author{
Fabio Bevilacqua \& Enrico Giannetto \\ Dipartimento di Fisica "A. Volta", Università di Pavia, \\ via A. Bassi 6, 27100 Pavia, Italia; GNSF/CNR, sezione di Pavia
}

\begin{abstract}
Eger's contribution towards a rapprochement of Hermeneutics, Science and Science Education is very welcome. His focus on the problem of misconceptions is relevant. All the same in our opinion some not minor points need a clarification. We will try to argue that: a) Hermeneutics cannot be reduced to a semantical interpretation of science texts; its phenomenological aspects have to be taken in account. b) Science has an unavoidable historical dimension; original papers and advanced textbooks are the real depositaries of scientific research. Standard textbooks are a caricature not worth it of a hermeneutical analysis. c) A parallelism can be traced between two couples of dycothomies: the lifeworld of hermeneutics and the scienceworld of a neo-positivist epistemology on one side and the extraordinary and the normal science on the other. d) For an overcoming of the misconceptions' problem we propose that the previous dycothomies be bridged through a hermeneutical phenomenological approach to science education that stresses the alternative, historical interpretations of natural phenomena.
\end{abstract}




\section{Introduction}

Martin Eger's papers ${ }^{1}$ on Hermeneutics, Science and Science Education are an interesting contribution to what we think is a relevant contemporary issue. Today traditional beliefs on the nature of science have been shaken: it is increasingly difficult to talk of "scientific progress", "scientific truth" disappears below the horizon, experiments are no more secure grounds for building theories but require themselves an interpretation, the distinction between human and natural sciences is ever more difficult to outline, Anglo-American philosophy of science has shown a renewed interest in continental European philosophy, and postmodernist philosophies tend to deny cognitive value to scientific theories and historiographers doubt that a "big picture" of scientific debates can be achieved. ${ }^{2}$ Constructivist and multiculturalist research programmes rise fierce discussions. ${ }^{3}$ It is not easy for science educators, to acquire an approach to science meaningful for contemporary educational purposes despite the fact that many contributions in recent years have shown a certain reapprochment between science education, history and philosophy of science. Given that this journal itself owes its life to this trend, Eger's approach is particularly wellcome because it brings to the attention of science educators themes of one of the most important contemporary debates: the one between hermeneutics and philosophy of science.

Nowadays, the international philosophical debates are largely influenced by hermeneutics. Hermeneutics is becoming a so called philosophical koine', that is: it is going to constitute a common background for dealing with any kind of philosophical question. One aspect of this trend is the very general linguistic turn in philosophy which, after Heidegger and Wittgenstein, has been marking both continental-existential and analytical perspectives: there is a common emphasis on language as the fundamental mean to deal with every philosophical issue. ${ }^{4}$ Furthermore, as part of the trend towards continental philosophy, some critical inquiries on the nature of science both within the analytical tradition itself and from post-positivist epistemological and historical points of view have lead to a post-analytic philosophy converging towards hermeneutics. ${ }^{5}$

Last year was held in Veszprèm (Hungary) the first International Conference on Hermeneutics and Science, and an International Society of Hermeneutics and Science is due to be founded this year.

Here, we would like to discuss only some major points of Eger's papers to outline how, in our opinion, hermeneutics can be relevant for science education and history of science. We shall always refer to physical sciences, but we believe that our considerations could be extended in some way to the other sciences.

\footnotetext{
${ }^{1}$ M. Eger, Science \& Education 1, 337-348, 1992; Science \& Education 2, 1-29 and 303-328, 1993.

${ }^{2}$ See for example: Companion to the History of Modern Science, ed. by R. C. Olby, G. N. Cantor, J. R. R. Christie and M. J. S. Hodge, Routledge, London 1990; BJHS

${ }^{3}$ M. Matthews, History, Philosophy and Science Teaching: A Useful Alliance, Routledge, New York 1994.

${ }^{4}$ K. O. Apel, Transformation der Philosophie, Suhrkamp, Frankfurt am Main 1973, 1976; R. Rorty (ed.), The Linguistic Turn, University of Chicago Press, Chicago 1967; M. Heidegger, Unterwegs zur Sprache, Neske, Pfullingen 1959; L. Wittgenstein, Logisch-philosophische Abhandlung. Tractatus logico-philosophicus, with an introduction by B. Russell, Kegan Paul, Trench, Trubner and Co., London 1922; L. Wittgenstein, Philosophische Untersuchungen. Philosophical Investiogations, Blackwell, Oxford 1953.

5 R. Rorty, Philosophy and the Mirror of Nature, Princeton University Press, Princeton 1979; R. Rorty, Is Natural Science a Natural Kind?, in Objectivity, Relativism and Truth. Philosophical Papers I, Cambridge University Press, Cambridge 1991, pp. 46-62..
} 
Paragraph 2 is dedicated to the problem of the so-called "misconceptions" in science education. In paragraph 3, we discuss the general relations between science and hermeneutics giving a comparison between Eger's and our perspective, and analysing again the problem of misconceptions from our point of view. In paragraph 4 we present very briefly one of our basic proposal: science as a historical process has hermeneutical features and history of science has to be considered as a hermeneutical practice. Paragraph 5 deals with the way the scientific context of interpretation individuated by Eger: in our opinion, hermeneutics becomes relevant in science education through history of science.

\section{Misconceptions: A First Look}

In his paper on Hermeneutics and Science Education, Eger points out that the well known problem of "misconceptions" is an indicator of the failures of contemporary educational efforts. We agree on that and we will utilise this issue as a ground for the discussion.

Among the most interesting proposed "solutions" to the problem of misconceptions is the constructivist one: misconceptions have been reinterpreted as "alternative conceptions". In such a framework, they are related to unavoidable different "mental representations" necessarily involved both in the learning processes and in the different semantical models that every theory implies. ${ }^{6}$ However, this kind of perspective gives us no explanation of the origin of this learning problem and does not allow a transition process from student mental representations to an actual understanding of science (a "conceptual change").

Indeed hermeneutics can give us a new insight on this issue: as Eger has shown, "misconceptions" have to be strictly related to "pre-conceptions". ${ }^{7}$ From a point of view that belongs to the hermeneutical tradition there are presuppositions ("pre-conceptions") in our knowledge constructions which constitute the conditions of possibility of our experience. They are not given within the subject of knowlede as for Kant, but they depend on the lifeworld we are embedded in. ${ }^{8}$ Thus, preconceptions are related to the basic way of "our being within the world" (Heidegger's Dasein). ${ }^{9}$

A scheme can roughly summarise this point:

\footnotetext{
${ }^{6}$ See, for example, E. Giannetto, C. Tarsitani \& M. Vicentini, The Relations between Epistemology, History of Science and Science Teaching from the Point of View of the Research on Mental Representations, in The History and Philosophy of Science in Science Education, ed. by S. Hill, Kingston 1992, pp. 359-374 and references therein.

${ }^{7}$ M. Eger, Science \& Education 1, 1992, in particular pp. 342-344

${ }^{8}$ Lifeworld is for the german Lebenswelt as introduced by Husserl: E. Husserl, Die Krisis der europäischen Wissenschaften und die transzendentale Phänomenologie, in Husserliana, Gesammelte Werke, v. 6, Nijhoff, Den Haag 1954, 1959.

9 M. Heidegger, Sein und Zeit, Niemeyer, Tübingen 1927; M. Heidegger, Die Frage nach der Technik, in Vorträge und Aufsätze, Neske, Pfullingen 1954; M. Heidegger, Wissenschaft und Besinnung, in Vorträge und..., op. cit.; M. Heidegger (1935-1946), Holzwege, Klostermann, Frankfurt am Main 1950; M. Heidegger, Unterwegs zur Sprache, Neske, Pfullingen 1959.
} 


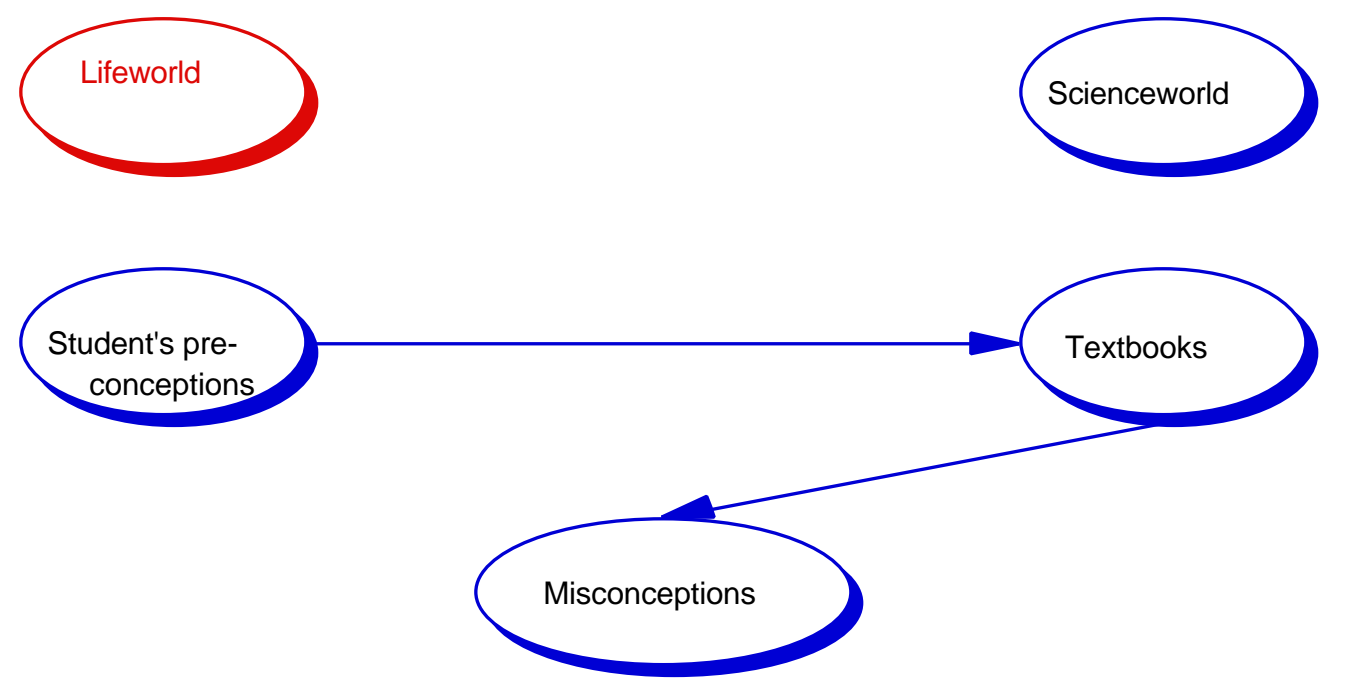

The student is embedded in his own daily life; he faces the world of science through the explanation of scientific results given in a textbook: the gap between the two worlds is such that misconceptions on the meaning of scientific theories result.

The problem could be avoided, from Eger's point of view, focussing on hermeneutic interpretation rather than on "epistemological" explanation. Bridging the horizon of physics and the horizon of lifeworld implies an extension of language and of concepts. ${ }^{10}$ Eger's papers thus rise two interesting and basic questions that we want to discuss: what shall we mean for hermeneutics, what is the specific contribution that hermeneutics can offer to science education? We will try to argue that a wider bridge than an extension is required.

10 M. Eger, Science \& Education 1, 1992, in particular p. 343. 


\section{Hermeneutics between Text Interpretation and Ontological Phenomenology: A New Look at Misconceptions}

Eger's starting point for the introduction of hermeneutics within science is the development of the famous Galilei's metaphor of nature seen as a "mathematical text". ${ }^{11}$ Science is seen as a language through which we give a hermeneutics of this text.

Eger is right that before Heidegger hermeneutics was essentially hermeneutics of texts, interpretation of texts. ${ }^{12}$ Embedding Husserl's phenomenology within his ontological perspective, Heidegger created a new kind of hermeneutics, where "interpretation" had first of all to be related to our existential conditions within the world. Galilei's metaphor of nature as a book, in our opinion, allows Eger to "identify" in some sense the two kinds of hermeneutics, the two kinds of interpretation. This major hypothesis seems to smooth out the differences between lifeworld and scienceworld, leading to see scienceworld concepts as mere extensions of lifeworld concepts and so deviates in some way from the "standard" (Husserl's, Heidegger's, Gadamer's) hermeneutical views. ${ }^{13}$

In their opinion, scienceworld is opposed to lifeworld as the artificial, isolated laboratory world and is related to instruments which, even if they could be considered in some respect as extensions of our senses, determine completely different conditions of possibility of experience: indeed, we could no more speak in terms of experience tout court.

While we do not want to enter into the problem of the appraisal of science in the perspective of Heidegger and Gadamer (they give a negative judgement of science and show its relations to technics), ${ }^{14}$ we believe that is important to not to hide the differences between lifeworld and scienceworld. We want to bridge and to smooth them through a better understanding of the problem of misconceptions and the historical development of science within the historical context of our lifeworld.

Indeed, experiments have a very different nature from lifeworld experiences: they are based on presuppositions related to the particular nature of instruments. Just to point out the major difference: experiments at variance with experience can be quantitatively treated and they allow the mathematization of physics.

An example we can look at the so-called scientific revolution, as well as Husserl before Heidegger had done, as the transition from an empirically grounded phyisics related to lifeworld experience to an experimentally grounded physics. ${ }^{15}$

From this point of view, in our opinion, also radical theoretical changes have to be understood and to be related to the introduction of scientific instruments that constrain us with different conditions of possibility of experience.

Coming back to the question of "misconceptions", we want to point out a sort of "existential conflict" that has its grounds in the deep layers of the science and in the actual differences between scienceworld and lifeworld. Misconceptions derive from the interpretation of science

\footnotetext{
${ }^{11}$ M. Eger, Science \& Education 1, 1992, in particular pp. 339-340; M. Eger, Science \& Education 2, 1992, in particular pp. 5-6 and 308-309.

12 M. Eger, Science \& Education 2, 1992, in particular pp. 5 and the following ones.

13 H. G. Gadamer, Wahrheit und Methode, Mohr, Tübingen 1960, 1965 and references quoted in notes 8 and 9.

14 See for this issue: E. Giannetto, Heidegger and the Question of Physics, Proceedings of the "Conference on Science and Hermeneutics" (Veszprém 1993), ed. by O. Kiss \& L. Ropolyi, Reidel, Dordrecht (in press).

15 See notes 8,9 and 14 .
} 
within the "categories" of our lifeworld experience. They can be avoided and a "conceptual change" can be achieved, if and only if we will clarify and bridge the differences between scienceworld and lifeworld, as well as the differences among the various conditions of possibility of our knowledge constructions.

Thus, even if, in our opinion, Eger's perspective gives a right suggestion to understand the questions involved in science education, his hermeneutical approach to science seems to neglect that hermeneutics is strictly related to our being within the lifeworld. The interpretation processes Eger suggests within science are in relation not to hermeneutics but only to semantics of the "idealizations" of the mathematical language and of experiments. That is, the scientific interpretation processes suggested by Eger seem not related to an "ontological understanding" but to an hypothetic-deductive and experimental kind of "explanation". Mathematical and experimental media are very different from a common language directly related to lifeworld experience: they cannot lead us to an understanding of the lifeworld but to the construction of a scienceworld. Thus, in our opinion, there cannot be a "double hermeneutics" for physical science but for different reasons from Habermas' ones: theoretical mathematical language is qualitatively different from natural language, being not directly related to lifeworld experience but to experiments, instruments and correspondent theoretical concepts. ${ }^{16}$

Eger outlines the existence of three contexts for science: discovery, justification and interpretation. ${ }^{17}$

The context of interpretation is also related to what elsewhere we have presented as the existence of different conceptual models as a component of science. ${ }^{18}$ Eger writes that all presentations and interpretations constituting this third context belong to the actual being of science. He however gives no indications on how to articulate science education within these three contexts and moreover all presentations and interpretations seem to have to be considered just on a continuous and homogeneous level.

In our opinion, this could lead to conceive the context of interpretation as converging to a non-historical plane where textbooks (TB) and original papers (OP) loose their differences in order to save the overall unitary aspect of science. That is, there would be a convergence to a non-historical plane where "extraordinary science" and "normal science" would be embedded in a unique semantical framework, with the risk of a complete "normalization" of science. This might be a consequence of the equivalence posed by Eger between lifeworld and scienceworld: both are seen as books, as texts. Moreover he discusses a hermeneutical approach to science (and not to history of science): he misses the historical features of science and the historical relations between lifeworld and scienceworld.

\section{Science between Textbooks and Original Papers}

Usually students face textbooks, but is difficult to see in what sense textbooks relate to science: not only, as well known, they leave out extraordinary science, but also the science they deal with is not that normal.

Ordinary textbooks for high school and undergraduates do not offer a coherent scientific theory of the phenomena: they offer layers of scientific results, coming from competing interpretations, deposited during centuries. A quantitative correspondence between the layers

\footnotetext{
${ }^{16}$ See this issue as discussed by Eger and references therein: M. Eger, Science \& Education 2, 1992, in particular pp. 305-308.

${ }_{17}^{17}$ M. Eger, Science \& Education 2, 1992, in particular p. 321 but see pp. 314-323.

18 F. Bevilacqua,
} 
cannot hide the general lack of a coherent meaning and the conflation of contrasting models. From one point of view textbooks are good for indoctrination, like catechisms, from another they offer a technical view of science, closer to operating manuals of modern artifacts than to science texts. A "hermeneutical"-semantical reinterpretation of these texts would hardly be of any benefit.

More interesting is the case of advanced textbooks (ATB), so called because usually addressed to graduate students, and often written by first rank scientists. Here an effort towards a conceptual coherence is certainly and beautifully done, but we soon understand that great scientists also in their advanced texts provide us with competing views. This is an indication that normal science is not that normal. Even in textbooks scientists express alternative interpretations and beliefs.

If we want to teach "science" these alternative interpretations have got to be outlined and clarified, not hidden and mistified. The dycothomy between normal science and extraordinary science does not hold. Reference to original papers, scientific debates, biographies and social contexts comes into play when we consider scientist' lifeworld, that is when we consider science from the point of view of hermeneutics as an ontological phenomenology. All science documents and science texts have an unavoidable historical nature. As with normal and extraordinary science, we can see the bridge between a lifeworld and a scienceworld: scientific achievements and scienceworld are definitely part of the lifeworld. Again, we can use a conceptual diagram to schematize our point of view:

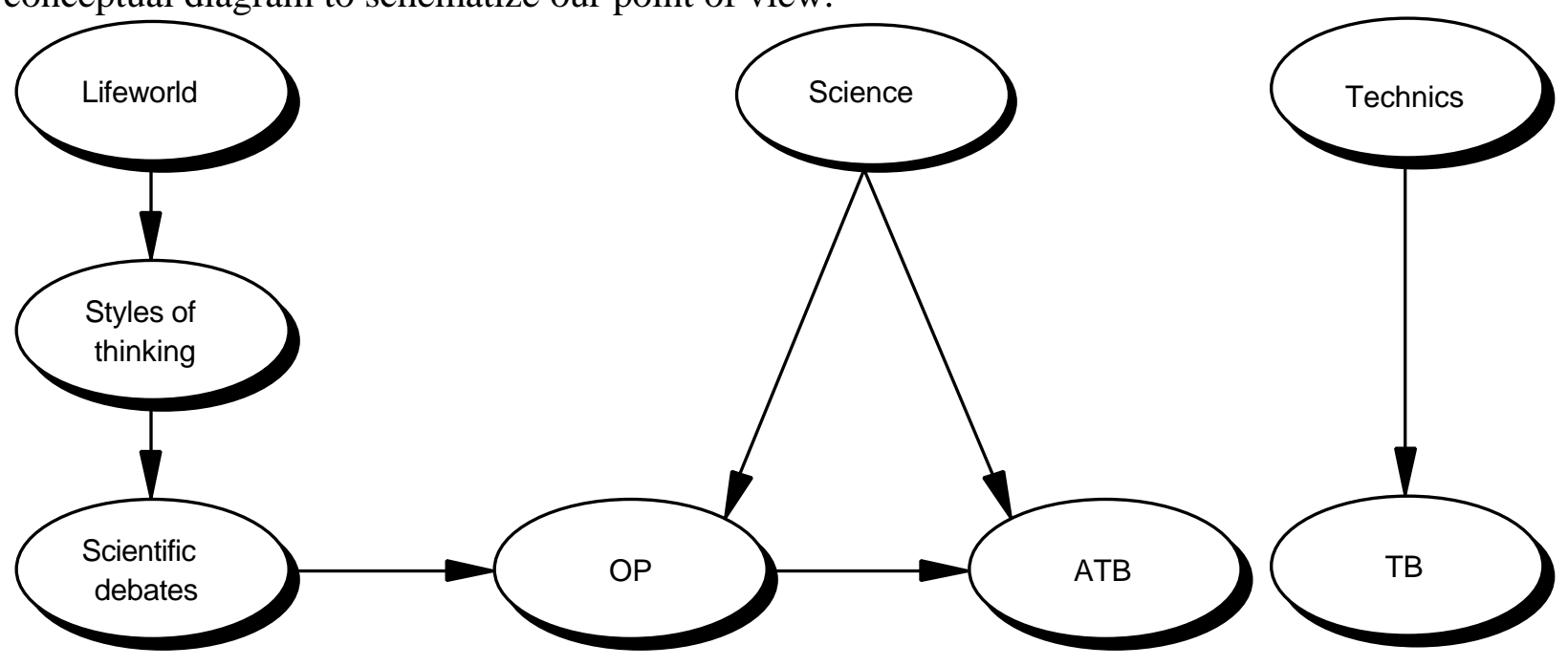

Looking at hermeneutics for science education would mean to exclude textbooks as related only to technical purposes, and to come back to the lifeworld where original scientific papers and advanced textbooks find their roots giving us an actual historical understanding of science.

\section{A Parallelism between two Dycothomies}

The contexts of discovery, justification and interpretation cannot be separated as long as they belong to a historical lifeworld. Identifying lifeworld with a text gives a semantical connotation to the context of interpretation. In this way, we miss the hermeneutics of history of science and of lifeworld, that is we miss the basic activities of extraordinary science, and we confine ourselves to epistemology of normal science. The possibility of an actual understanding of 
conceptual changes in science is given up. From this point of view, also science education would be reduced to an understanding of a normalized science.

If we assume a hermeneutical point of view, on the contrary, teaching physics has to be connected to teaching history of physics, that is physics within the historically determined lifeworlds that give rise to its practices.

We can describe this situation by means of a conceptual diagram:

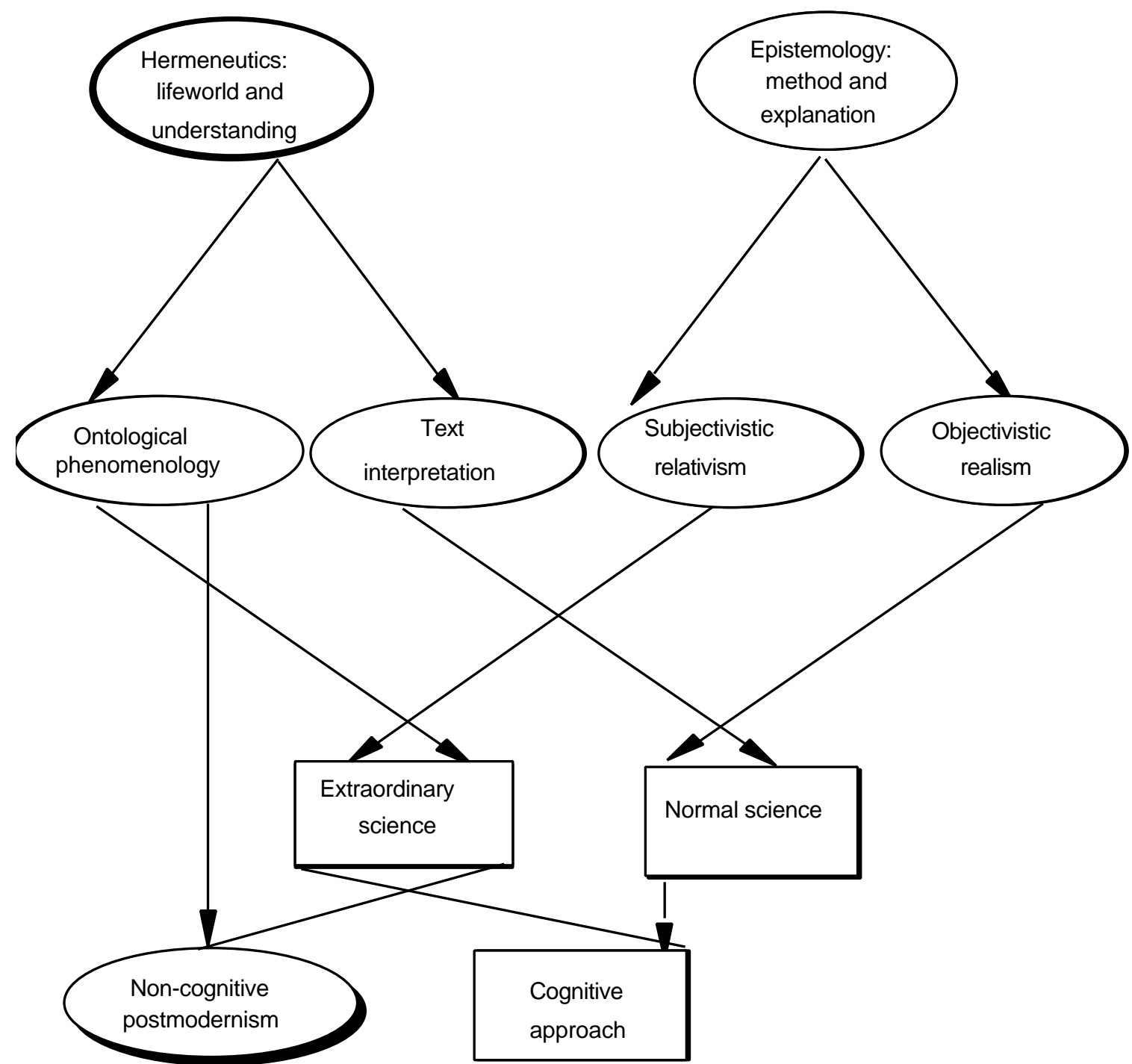

This schematizes a parallelism between two dycothomies: the lifeworld of hermeneutics and the scienceworld of a neo-positivist epistemology on one side and the extraordinary and the normal science on the other. On one side, if we follow epistemology, we can assume an objectivistic realism to understand normal science, but an understanding of extraordinary science seems to require a subjectivistic relativism. On the other side, if we understand hermeneutics as text interpretation, hermeneutics could lead us simply to a mere interpretation of normal science; on the contrary, if we understand hermeneutics as an ontological phenomenology of lifeworld, hermeneutics could lead us to an actual understanding of extraordinary science, that is of science as research in its cognitive and non-cognitive aspects, without going through any epistemological subjectivism.

\section{Hermeneutics and History of Science}


From our point of view, the extended Galilei's hypothesis of the book of nature is not the correct way to approach science as a hermeneutical practice.

Let us ask how science appears from a hermeneutical point of view. Assuming an interpretation of the scientific revolution as the transition from an empirically grounded phyisics related to lifeworld experience to an experimentally grounded physics, we should focus the historically given bridge between lifeworld and scienceworld. This can be done analysing the hermeneutical presuppositions of science, that is the specific lifeworld conditions of the possibility of science. We should give priority to a historical analysis of science, pointing out also the biological, anthropological, sociological, psychological peculiarities of a particular historical lifeworld and relating ontological, epistemological, logico-mathematical and experimental presuppositions of physical theories (science) to the lifeworld in which they are constructed.

These simple considerations indeed can lead us to explore an hermeneutical approach to the history of physics (science): that is, science is a historical process and as such it has hermeneutical features, as well as history of science is a hermeneutical practice that reveals us them. ${ }^{19}$ Looking at physical theories as embedded within the historicity of lifeworld, as events in lifeworld, as well as looking at histories of physics as embedded within the historicity of lifeworld. That is, we would have to find the conditions of possibility of historical knowledge (of science, of physics) just in the fact that our being and our practices, scientific as well as historical ones, are related to a historically changing lifeworld.

Furthermore, we can look at the hermeneutical origin of scientific concepts from lifeworld experience: space, time, motion, etc. , just like philosopher-scientistis as Poincaré, Russell or Whithehead or others have done. ${ }^{20}$

Another suggestion could be to look at the hermeneutical (common language) "metaphorology" as "constitutive" of scientific theories as Boyd, Kuhn or Blumenberg have done:21 the Galilei metaphor of the "book of nature", recalled by Eger too but for an assissment of an hermeneutical science and not, as in our opinion, for showing the hermeneutical presuppositions and origins of scientific theories; the metaphor of uniformity, unity of nature; and so on.

Moreover, we could look at the results of science from a hermeneutical point of view whenever theories, experiments, mathematics no more give us a quantitative, exact, predicting, deterministic explanation but only a qualitative, uncertain, unable to predict, indeterministic, subject-within-the-world-dependent understanding: that is, when we can say that mathematical

\footnotetext{
19 This was also a suggestion given, among others, by K. O. Apel: K. O. Apel, History of Science as a Problem of Hermeneutics. An Argument with Karl Popper's "Third-World"-Hermeneutics, Proceedings of the "Conference on Science and Hermeneutics" (Veszprém 1993), ed. by O. Kiss \& L. Ropolyi, Reidel, Dordrecht (in press).

20 See for example the following books where the authours try to find a "foundation" for science within lifeworld experience: H. Poincaré, La science et l'hypothèse, Flammarion, Paris 1902; H. Poincaré, La valeur de la science, Flammarion, Paris 1905; B. Russell, Our Knowledge of the External World, Cambridge University Press, Cambridge 1914; A. N. Whitehead, The Concept of Nature , Cambridge University Press, Cambridge 1920.

21 H. Blumenberg, Paradigmen zu einer Metaphorologie, Bonn 1960; H. Blumenberg, Die Lesbarkeit der Welt, Frankfurt am Main1981; R. Boyd, Metaphor and Theory Change: What is "Metaphor" and Metaphor for?, in Metaphor and Thought, ed. by A. Ortony, Cambridge University Press, Cambridge 1979; T. S. Kuhn, Metaphor in Science, in Metaphor and Thought, ed. by A. Ortony, Cambridge University Press, Cambridge 1979.
} 
language collapses to a qualitative symbolic language like common language and that experiments collapse to the ambiguities of qualitative subjective experience. ${ }^{22}$

\section{A Possible Bridge}

We will try to utilise the two points discussed (a hermeneutical approach to history of science that offers an open but not subjectivistic interpretation of nature and a view of science that stresses the historical nature of all science texts) for outlining a proposal for science educators.

We will refer to the work of G. Buchdal who recently contributed to this journal, ${ }^{23}$ showing how it can be related to a hermeneutical perspective. From Buchdal's point of view, a phenomenon can undergo several different phases of a so-called process of reductionrealization (RR): in the reduction process it looses all the theoretical aspects that shape it, while in the realization process it acquires a new interpretation and thus a new possibility of existence. The reduction process would mean a husserlian phenomenological epoché which lead us back to the lifeworld. The realization process would be related to the different possible hermeneutical interpretations linked to the different possibilities of our way of being within the world.

If we accept that this dynamic process can be a key to explaining the scientists' inovative meaning shift to a new interpretation, that is to a new scientific theory, a version of it can be used to shape an educational framework. The student could be guided to understand the different interpretations (realizations) of a given phenomenon offered by scientists considering their lifeworld, and in choosing and utilising one or the other (and thus achieving himself a RR process) he could come close to the actual aspects of scientific research. The reductionrealization process in education would havee diacronical aspects, strictly connecting science learning with history and philosophy of science. While allowing quite a role for the subjectivity of the student, this approach links it to the achievements of the scientific tradition. That is: in education (like in science) the convergence towards a "truth" is given up, but scientific theories are seen in their complexity as full of cognitive and non-cognitive values and radical subjectivism, relativism are avoided through a close reference to scientific debates within lifeworld. Again, a conceptual diagram can help us to schematize:

22 E. Giannetto, Heidegger and the Question of Physics, Proceedings of the "Conference on Science and Hermeneutics" (Veszprém 1993), ed. by O. Kiss \& L. Ropolyi, Reidel, Dordrecht (in press); E. Giannetto, Toward a Quantum Epistemology, in Atti del Convegno S.I.L.F.S. Temi e Prospettive della Logica e della Filosofia della Scienza, ed. by M. L. Dalla Chiara \& M. C. Galavotti, CLUEB, Bologna 1988, pp. 121-124.

23 G. Buchdal, Kant and the Dynamics of Reason, Blackwell, Oxford 1992. 


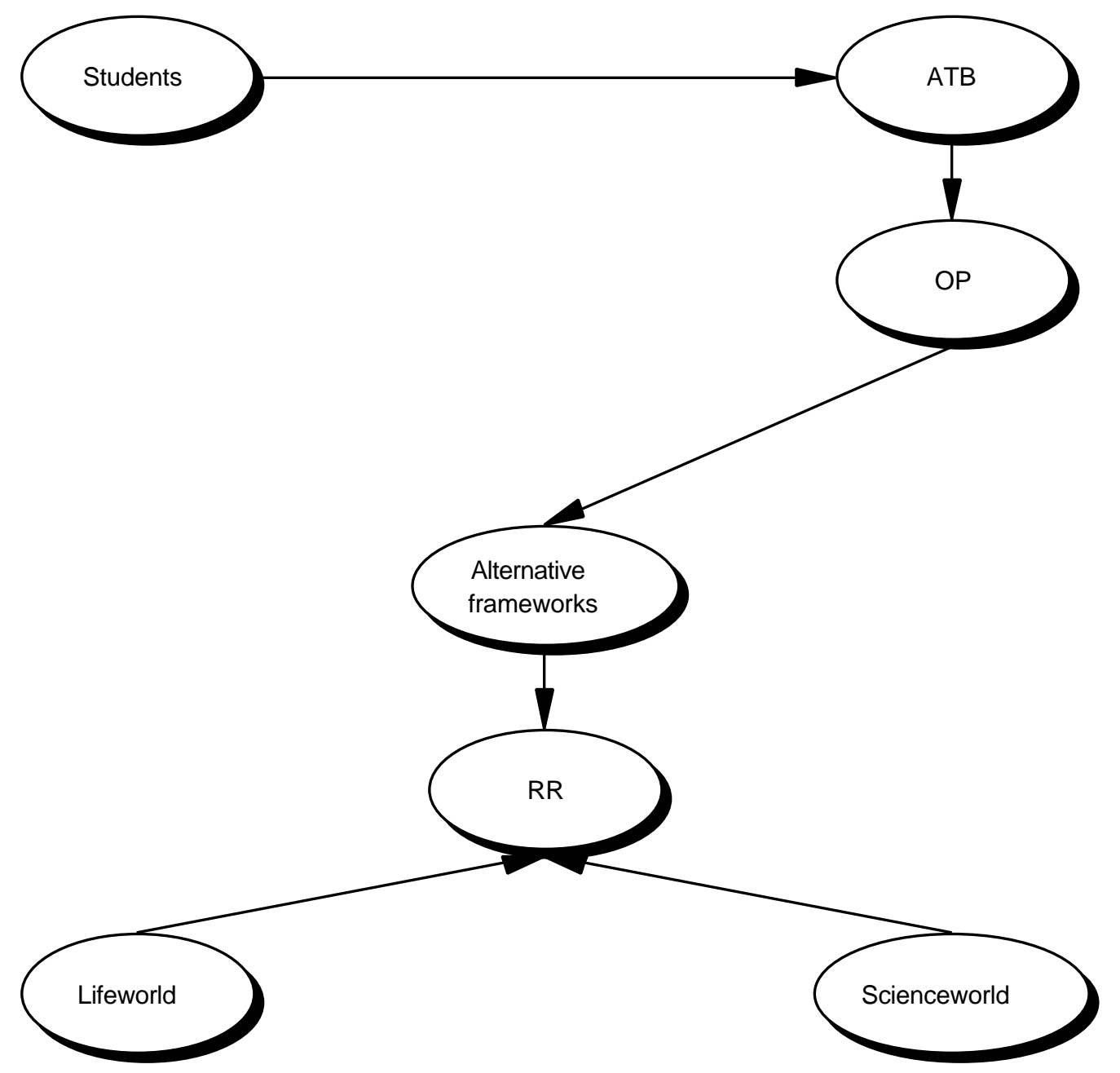

Thus, the student can hermeneutically (historically) follow again the path from lifeworld to scienceworld and we can find a bridge between lifeworld and scienceworld without any simple identification or mere extension of language.

Let us give a couple of example to try to clarify our proposal: students of mechanics generally embedded in an Aristotelian interpretation of the fall of bodies, are supposed to learn Galileo's kinematic approach, than they shift to Newton's dynamical one, then perhaps to Einstein's geometrical reinterpretation. Students of electromagnetism learn of Coulomb law of action at a distance, but also of potential theory, of Faraday's and Maxwell's contiguous action and field theory, to mention only the best known models of electrical phenomena. Is the quantitative correspondence in the appropriate domains between most of these alternative interpretation ("numerical convergence") sufficient to give coherence to the students conceptions? Certainly not, and here a need for a different role of interpretation, a "hermeneutics", comes into play. But what sort of hermeneutics? In our view certainly not an attempt at a convergence towards a unique final meaning of the fall of bodies or of electrical action to be achieved through a deeper analysis of a textbook. What would be needed instead is a historical clarification of the 
specific individual interpretations of the authors implied, and of the reasons they had for shifting from one meaning to the other as embedded in their own lifeworld. This can be done focussing on sources other than textbooks. The capability to "realize" the phenomenon in alternative ways, and thus to perform the meaning shift from one to the other, is the "hermeneutical" approach to science education that, in our opinion, might get rid of the "misconceptions" problem. 


\section{References}

K. O. Apel, Transformation der Philosophie, Suhrkamp, Frankfurt am Main 1973, 1976.

K. O. Apel, History of Science as a Problem of Hermeneutics. An Argument with Karl Popper's "Third-World"-Hermeneutics, Proceedings of the "Conference on Science and Hermeneutics" (Veszprém 1993), ed. by O. Kiss \& L. Ropolyi, Reidel, Dordrecht (in press).

F. Bevilacqua, Textbooks Physics Versus History of Physics: The Case of Classical Electromagnetic Theory, in The Principle of Conservation of Energy and the History of Classical Electromagnetic Theory, La Goliardica Pavese, Pavia 1983, pp. 1-34, 231-244.

F. Bevilacqua, "Enchantment" and the Post Industrial Society, in P. Thomsen (ed.), Science Education and History of Physics, Physics Dept., University of Aarhus, Aarhus 1986, pp. 4254.

H. Blumenberg, Paradigmen zu einer Metaphorologie, Bonn 1960.

H. Blumenberg, Die Lesbarkeit der Welt, Frankfurt am Main1981.

R. Boyd, Metaphor and Theory Change: What is "Metaphor" and Metaphor for?, in Metaphor and Thought, ed. by A. Ortony, Cambridge University Press, Cambridge 1979.

G. Buchdahl, Kant and the Dynamics of Reason, Blackwell, Oxford 1992.

G. Buchdahl,

M. Eger, Science \& Education 1, 337-348, 1992; Science \& Education 2, 1-29 and 303-328, 1993.

H. G. Gadamer, Wahrheit und Methode, Mohr, Tübingen 1960, 1965.

E. Giannetto, Heidegger and the Question of Physics, Proceedings of the "Conference on Science and Hermeneutics" (Veszprém 1993), ed. by O. Kiss \& L. Ropolyi, Reidel, Dordrecht (in press).

E. Giannetto, Toward a Quantum Epistemology, in Atti del Convegno S.I.L.F.S. Temi e Prospettive della Logica e della Filosofia della Scienza, ed. by M. L. Dalla Chiara \& M. C. Galavotti, CLUEB, Bologna 1988, pp. 121-124.

E. Giannetto, C. Tarsitani \& M. Vicentini, The Relations between Epistemology, History of Science and Science Teaching from the Point of View of the Research on Mental Representations, in The History and Philosophy of Science in Science Education, ed. by S. Hill, Kingston 1992, pp. 359-374.

M. Heidegger, Sein und Zeit, Niemeyer, Tübingen 1927.

M. Heidegger, Die Frage nach der Technik, in Vorträge und Aufsätze, Neske, Pfullingen 1954.

M. Heidegger, Wissenschaft und Besinnung, in Vorträge und..., op. cit.

M. Heidegger (1935-1946), Holzwege, Klostermann, Frankfurt am Main 1950.

M. Heidegger, Unterwegs zur Sprache, Neske, Pfullingen 1959.

E. Husserl, Die Krisis der europäischen Wissenschaften und die transzendentale Phänomenologie, in Husserliana, Gesammelte Werke, v. 6, Nijhoff, Den Haag 1954, 1959.

T. S. Kuhn, Metaphor in Science, in Metaphor and Thought, ed. by A. Ortony, Cambridge University Press, Cambridge 1979.

M. Matthews, History, Philosophy and Science Teaching: A Useful Alliance, Routledge, New York 1994.

R. C. Olby, G. N. Cantor, J. R. R. Christie and M. J. S. Hodge (eds.), Companion to the History of Modern Science, Routledge, London 1990

H. Poincaré, La science et l'hypothèse, Flammarion, Paris 1902.

H. Poincaré, La valeur de la science, Flammarion, Paris 1905.

R. Rorty (ed.), The Linguistic Turn, University of Chicago Press, Chicago 1967. 
R. Rorty, Is Natural Science a Natural Kind?, in Objectivity, Relativism and Truth. Philosophical Papers I, Cambridge University Press, Cambridge 1991, pp. 46-62.

R. Rorty, Philosophy and the Mirror of Nature, Princeton University Press, Princeton 1979.

B. Russell, Our Knowledge of the External World, Cambridge University Press, Cambridge 1914.

A. N. Whitehead, The Concept of Nature, Cambridge University Press, Cambridge 1920

L. Wittgenstein, Logisch-philosophische Abhandlung. Tractatus logico-philosophicus, with an introduction by B. Russell, Kegan Paul, Trench, Trubner and Co., London 1922.

L. Wittgenstein, Philosophische Untersuchungen. Philosophical Investiogations, Blackwell, Oxford 1953. 